\title{
The Immediate Impact of COVID-19 on Law Enforcement in the United States
}

\section{Wesley G. Jennings ${ }^{1} \cdot$ Nicholas M. Perez ${ }^{2}$}

Received: 10 April 2020 / Accepted: 29 May 2020 /

Published online: 6 June 2020

(C) Southern Criminal Justice Association 2020

\begin{abstract}
During pandemics, like COVID-19, law enforcement agencies are responsible for working with government and public health officials to contain spread, serve the local community, and maintain public order. Given the person-to-person spread of COVID19 through respiratory droplets, law enforcement officers are also at a heightened risk of exposure due to their close contact with members of the public. To protect officers, the Centers for Disease Control and Prevention (CDC) and other agencies have made numerous recommendations for law enforcement agencies to protect officers and the public. Departments around the country have responded to the pandemic in various ways, such as reassigning personnel to high-traffic areas, suspending training, roll calls, and community outreach initiatives, only issuing citations for low-level crimes, implementing safety precautions for officers, and limiting access to department facilities. The COVID-19 pandemic also has exposed some key obstacles for law enforcement, related to communication, resource management, the enforcement of public health restrictions, and changes to crime and service patterns. Based on these early/ initial responses and obstacles during the COVID-19 outbreak, the current paper highlights directions for future responses to pandemics to ensure the safety and security of police officers and the communities they serve.
\end{abstract}

Keywords Police $\cdot$ Coronavirus $\cdot$ COVID-19 $\cdot$ Epidemic $\cdot$ Pandemic $\cdot$ Public health $\cdot$ Criminal justice

Wesley G. Jennings

wgj@olemiss.edu

Nicholas M. Perez

Nicholas.Perez@csulb.edu

1 School of Applied Sciences, Department of Criminal Justice \& Legal Studies, The University of Mississippi, 84 Dormitory Row West, H313, P.O. Box 1848, University, Oxford, MS 38677-1848, USA

2 School of Criminology, Criminal Justice, and Emergency Management, California State University, Long Beach, 1250 Bellflower Blvd., ET-226, Long Beach, CA 90840, USA 
As countries all over the world, every state and territory in the United States, and jurisdictions both urban, suburban, and rural are grappling with the societal, public health, and economic impacts of COVID-19, there has never been a more important time than the current to assess the immediate effects of the pandemic on law enforcement in the United States and to highlight law enforcement's best practices and strategies currently being implemented to "flatten the curve", ensure public safety, and to protect law enforcement officers. As such, the current paper offers such a contribution by reviewing the historical impact of pandemics on law enforcement in the United States, summarizing existing COVID-19 recommendations for law enforcement responses, providing examples of local law enforcement responses to COVID-19, identifying obstacles for law enforcement responses to COVID-19, and offering directions to law enforcement for future responses to pandemics.

\section{Historical Impact of Pandemics on Law Enforcement in the United States}

Similar to man-made or naturally-occurring critical incidents that cause physical damage, such as terrorism, hurricanes, or earthquakes, a virus pandemic affects how local law enforcement agencies operate in various ways (Brito, Luna, \& Sanberg 2009). Most critical incidents, though, only affect a limited geographic area and do not last very long, allowing other non-affected agencies to aid the community throughout the most severe phases of the incident (Brito et al. 2009). A pandemic, on the other hand, affects multiple regions at once and can continue for an extended period of time, creating challenges at local, state, federal, and even global levels. During a pandemic, law enforcement agencies and officers play a crucial role to provide necessary public services and maintain order (Richards, Rathbun, Brito, \& Luna 2006). Although each public health emergency is unique with its own challenges, in all incidents, law enforcement responses must be coordinated with public health, medical, and other essential service authorities (Richards et al. 2006).

In the U.S., every state has a public health act, which allows the state's health officials to enact measures, such as social distancing, isolation, quarantine, travel restrictions, contact tracing, treatment, and vaccination, to protect the health of residents during a pandemic (Rothstein 2015). Local and state law enforcement is often tasked with explaining and enforcing these measures in the community (Rothstein 2015). Since law enforcement is "inherently close-contact work with strangers and some of the most marginalized people," police officers are on the front lines when dealing with pandemics and enforcing response measures, while simultaneously being at a greater risk of exposure and infection (Poston 2020).

In past outbreaks and pandemics, such as the H1N1 Flu in 1918, Severe Acute Respiratory Syndrome (SARS) in 2002, and the H1N1 Flu in 2009, law enforcement agencies were responsible for working with government and public health officials to contain spread, serve the local community, and maintain public order (Muckenfuss 2020). The H1N1 Flu pandemic in 1918 was the worst pandemic of the twentieth century in the United States, resulting in the deaths of 675,000 in the United States and approximately 50 million people worldwide (Luna, Brito, \& Sanberg 2007). During this pandemic, law enforcement agencies around the U.S. banned large public 
meetings, and shut down schools, churches, and theaters (Plaue \& Colarossi 2020). Furthermore, police officers were responsible for patrolling "quarantine zones" and hot spots to reduce the spread of the flu (Muckenfuss 2020). Beyond their role in the enforcement of response measures, officers are also over-exposed to the pandemic and the risk of infection relative to many other professions (CDC, 2020). Accordingly, personal protective equipment (PPE) has become essential for law enforcement officers to decrease these health risks (Sanberg, Brito, Luna, \& McFadden 2010). For example, during the SARS outbreak in Canada, the Toronto Police Service's (TPS) Occupational Health and Safety Unit was responsible for providing PPE and vital information to agency personnel and protecting the force from infection (Sanberg et al. 2010).

\section{COVID-19 Recommendations for Law Enforcement Responses}

Given the person-to-person spread of COVID-19 through respiratory droplets, law enforcement officers are at a heightened risk of exposure due to their close contact with members of the public (CDC, 2020). The Centers for Disease Control and Prevention (CDC, 2020) guidelines suggest: 1) social distancing (maintaining a distance of six-feet from other individuals to avoid exposure), 2) maintaining proper hand hygiene (washing hands with soap and water for at least 20 seconds), and 3) avoiding touching one's face with unwashed hands. Law enforcement officers, though, cannot carry out many of their duties without being in close personal contact with other people and may not have immediate access to all necessary sanitization supplies in the field (Barr 2020). Furthermore, officers working in or around correctional facilities are especially at risk of contracting and spreading the virus due to the close quarters (Maruschak, Sabol, Potter, Reid, \& Cramer 2009). By early April 2020, over two thousand law enforcement officers had already tested positive for COVID-19 (the vast majority in New York City), and thousands more officers reported exposure to an individual with the virus (Cave \& Dahir 2020; NPF, 2020). This has led to increased concern among officers about their health and the health of their families (Schuppe 2020).

Beyond the dangers associated with close contact with the public, the COVID-19 pandemic has also highlighted the potential for intentional contamination of officers. In March of 2020, the Federal Bureau of Investigation (FBI) alerted local police agencies that extremist groups, such as neo-Nazis and white supremacists, have encouraged their members who contract COVID-19 to intentionally spread the virus to police officers by spraying bodily fluids on police officers on the streets (Margolin 2020). Police officers have also reported incidents of being spat at or coughed on by people claiming to be positive for the virus (Bates 2020). To protect their officers and decrease these risks, agencies nationwide have transitioned many of their personnel to working remotely if possible (Bates 2020; NPF 2020).

To prevent further infection, the CDC (2020) outlined protective recommendations for first responders, such as law enforcement officers, who anticipate they may come into contact with persons infected with COVID-19. These CDC recommendations include: wearing PPE, such as disposable gloves, disposable gowns or coveralls, particulate respirator [N-95 designation or higher, that is approved by the National Institute for Occupational Safety and Health (NIOSH); if N-95 respirators are unavailable, a facemask was listed as an alternative until supply chains are restored], and eye protection (such as goggles or a 
disposable face shield). Furthermore, the CDC (2020) recommends that, should an officer come into contact with an individual during apprehension, they should clean and disinfect all gear prior to reusing, follow procedure to properly contain and dispose of the PPE, and follow procedure to properly contain and launder clothing. If agencies and officers follow these recommendations, the $\mathrm{CDC}$ estimated that the health risk for law enforcement personnel would remain low (CDC, 2020).

The Vera Institute of Justice (2020) provided further guidance on preventative and responsive measures for law enforcement officers. Their guidance prioritizes prevention in several key ways, suggesting that agencies should: (1) ensure that 911 dispatchers divert calls-for-service to health resources when a police response is not necessary; (2) issue temporary directives to release individuals on a citation/ticket/ summons unless they have committed a felony or pose an immediate risk to public safety; (3) suspend protocols that place people in custody (limiting enforcement of bench warrants, arrest warrants, and probation or parole violations); (4) limit police response to low-risk incidents to focus on critical incidents and community health needs (such as traffic stops, noise complaints, etc.); (5) limit officers who come into contact with department visitors; (6) expand online reporting options for complaints or police reports; and (7) increase cleaning and disinfecting of patrol cars, precincts, stations, and other high-traffic areas (Vera Institute of Justice 2020, p.2).

Vera's recommendations also involve containment measures, suggesting that agencies should: (1) use a CDC-informed screening tool to identify possible exposure and high-risk individuals; (2) develop a written policy and training for staff to separate people and maximize distance between those who are at higher risk and those who are asymptomatic; and (3) minimize contact between officers by suspending roll-call and using videoconferencing and other technology (Vera Institute of Justice 2020, p.2-3). Finally, Vera's guidance also calls for swift response by: (1) creating a written protocol and training on how to respond to active cases; and (2) developing policies for paid sick leave, staffing substitutions, and triage in the event of a personnel member testing positive for COVID-19 (Vera Institute of Justice 2020, p.3).

Police associations and advocacy agencies, such as the International Association of Chiefs of Police, the National Police Foundation (NPF), and PoliceOne, have provided resources and fact sheets to educate officers about COVID-19, and its spread, symptoms, and treatment (IACP, 2020; NPF, 2020; PoliceOne 2020). In addition to providing resources, the NPF, (2020) even provided a COVID-19 Law Enforcement Impact Dashboard to track personnel exposed by state and type of agency (municipality, county, state, campus, etc.), those unable to work, and those positive for COVID-19. The dashboard also tracks the availability of PPE and the most-needed PPE by agency, and is regularly updated by agencies nationwide (NPF, 2020).

\section{Local Law Enforcement Responses to COVID-19}

Based on these recommendations, the Vera Institute of Justice (Stagoff-Belfort 2020), the Brennan Center for Justice (2020), and the Police Executive Research Forum (2020) each have highlighted various best practices for dealing with COVID-19 from police departments around the country. Some agencies, such as the Camden Police Department, the Mountain View Police Department, and Santa Cruz Police 
Department, were commended for their established policies and procedures outlined for responding to the pandemic (NPF, 2020). Other agencies have adopted and communicated specific initiatives to respond to COVID-19; some of the agencies utilizing these responses are outlined below.

For example, in the immediate aftermath of the pandemic, the Los Angeles Police Department (LAPD) shifted many detectives and other personnel to daily patrol in highly visible areas, while the Los Angeles County Sheriff's Department (LASD) assigned deputies from more specialized units to work in crowded public areas, such as grocery stores, to help maintain public order (Winton \& Tcheckmedyian 2020). To reduce the likelihood that all officers in the agency will be exposed at once, the Tempe Police Department (Arizona) instituted a 50/50 work plan, dividing the agency's employees in half and keeping the two groups completely separate from one another (PERF, 2020). In Santa Cruz County (California), the Sheriff's office created a specialized Compliance Contact Team where deputies were specifically reassigned to recreational areas in the county, such as beaches and parks, to find social gatherings of groups and direct individuals to disperse (York 2020). Nationwide, in-person roll calls and in-service training have been suspended by numerous agencies (NPF, 2020).

In an effort to further limit the amount of contact with the public, the Metropolitan Nashville Police Department developed a program to handle non-emergency and nonviolent calls for service (such as minor vehicle crashes, lost or stolen property, shoplifting, and vandalism) in order to assess if a police report can be completed entirely via telephone (NPF, 2020; Osborne 2020). Furthermore, the LAPD and LASD implemented a cite-and-release program for misdemeanors, resulting in substantial decreases in the number of arrests made in the Los Angeles area and hundreds fewer inmates in their correctional facilities (Poston 2020; Winton \& Tcheckmedyian 2020). In Florida, the Miami-Dade Police Department instructed officers to issue citations for all misdemeanors, unless in the case of exigent circumstances, and temporarily restricted the enforcement of evictions citywide (Iannelli 2020; Lipscomb 2020). Law enforcement agencies in various other cities, such as Philadelphia, Chicago, Denver, San Francisco, Rockford (Illinois), Phoenix, and Fort-Worth (Texas), have made similar announcements that officers would temporarily only issue citations for low-level misdemeanors (Barba 2020; Garcia 2020; Haas 2020; Mallin \& Barr 2020; Manna 2020; Melamed \& Newell 2020; NPF, 2020). In fact, Fort-Worth officers were prohibited from making arrests for certain misdemeanors without prior supervisor approval (Manna 2020). Some police departments, such as Chula Vista (California), even used drones to patrol and enforce social distancing (Kucher 2020).

Across the U.S., various community-oriented policing and outreach initiatives have been cancelled or modified due to the close proximity between officers and members of the public (NPF, 2020). Due to social distancing guidelines, officers are being required to spend more time in their patrol cars and interact with community members less (Hermann, Morse, \& Jackman 2020). In the Metropolitan Police Department in Washington, DC, community activities such as "Coffee with a Cop" and community member walks with the Chief have been put on hold indefinitely (Hermann et al. 2020). To prevent their police-community relationships from fracturing in Washington, DC, the police have held community meetings via conference call instead of in-person (Hermann et al. 2020). 
Generally, all agencies have implemented additional safety precautions for their officers (NPF, 2020). Dispatchers in some agencies, such as the Dallas Police Department and the Harford County Sheriff's Office (Maryland), were instructed to ask 911 callers about possible COVID-19 symptoms to reduce first responder exposure (Schutz 2020; Whitlow 2020). If the caller is symptomatic, the responding officers are instructed to maintain distance and be sure to properly use their PPE (Whitlow 2020). For officers working in the field, the LAPD issued safety kits, including gloves, masks, and goggles for officers to wear when approaching a member of the public (Winton \& Tcheckmedyian 2020). To remind their officers about personal safety measures, the Kansas City Police Department (Missouri) frequently sent messages to officers on patrol to remind them to wash their hands and practice social distancing (Barr 2020). Relatedly, the Topeka Police Department implemented a public health regimen for all officers based on the aforementioned CDC guidelines and set up disinfecting and sanitization areas in all of their facilities (Martin 2020).

Other departments, such as the Omaha Police Department, closed their precincts to the public, instead opting to utilize call centers to handle public reports of incidents (Conley 2020). The Miami PD has limited both visitor and employee (including patrol officer) access to buildings by screening individuals entering the building for possible symptoms and even checking an individual's temperature to check for a fever (Browning 2020). The Phoenix PD recommended the public utilize their online crime reporting system instead of reporting crimes in-person or even calling 911 (Garcia 2020). Each of these protocols have been implemented in an effort to reduce person-toperson contact and to distance agency employees from members of the public wherever possible.

\section{Obstacles for Law Enforcement Responses to COVID-19}

\section{Communication}

Through the experiences and responses of law enforcement in the first weeks of the COVID-19 pandemic in the U.S., certain key obstacles can be identified. The first major obstacle involves communication and collaborations. While public health departments lead the actual response to the pandemic, law enforcement agencies are expected to be "the voice of authority, calm, and guidance" (Brito et al. 2009, p.1). The police are often tasked with communicating voluntary measures, such as social distancing, and mandatory measures, such as quarantines and mandatory lockdowns, and the consequences for violations (Brito et al. 2009; Garcia 2020). For example, Phoenix PD officers were assigned to go to local businesses to explain the statewide orders and educate staff about safety measures (Garcia 2020). This may also involve communicating the value of compliance with these measures for the common good and reassuring frightened residents (Brito et al. 2009).

This messaging should be developed in collaboration with local hospitals and public health agencies to ensure consistency and up-to-date information (Barr 2020; Richards et al. 2006). To promote voluntary compliance with these public health measures, positive police-community relationships and public trust are imperative (Richards et al. 2006). In addition to contacts with individuals outside of the department, internal 
communication is also essential for disseminating consistent and timely information to personnel about personal health measures, public safety initiatives, and other relevant news to reduce confusion and potential risks to officers (Sanberg et al. 2010).

\section{Resource Management}

A second major obstacle for police agencies involves departmental resource management (financial, personnel, equipment, etc.). Although many police departments plan for public health emergency situations and train officers about pandemic responses (Barr 2020), many small police departments and sheriff's offices were still underprepared for the vast effects of the COVID-19 pandemic (Bates 2020; Schuppe 2020). Even for agencies that did prepare, law enforcement resources can be quickly exhausted when dealing with the new responsibilities related to community health issues in addition to their routine service demands (Richards et al. 2006). The financial burden for agencies can be a major issue, as unforeseen costs for occupational health and safety programs, PPE and storage, liability, and other essential resources pile up (Brito et al. 2009; Sanberg et al. 2010).

During a pandemic like COVID-19, it is essential that law enforcement officers do not report to work while sick, as the virus could quickly spread through the department, and as a result, the community (Richards et al. 2006). That said, paid sick leave for department personnel is often limited and officers taking extra sick days as a precaution may not be feasible (Richards et al. 2006). As more officers are exposed, infected, or caring for sick loved ones, the overall workforce of law enforcement officers will be reduced (Bates 2020; Brito et al. 2009; Richards et al. 2006; Waldrop 2020). This could have been further exacerbated because, in the immediate aftermath of the pandemic, many departments did not have enough PPE and could not obtain a sufficient supply to protect their officers (NPF, 2020; Schuppe 2020). During the first month of the COVID-19 pandemic, the most commonly depleted and desired PPE items included respirators, gowns, and eye protection (NPF, 2020).

\section{Public Health Restrictions Enforcement}

A third major obstacle for police agencies relates to the enforcement of public health orders. By early April 2020, the majority of the world had been placed on stay-at-home orders, whether voluntary or compulsory (Cave \& Dahir 2020). Across the world, these orders vary in the activities that are prohibited and the penalties for citizen violations; some countries authorized their police to arrest and even shoot violators of the orders (Cave \& Dahir 2020). Depending on the reach and severity of these orders, the measures may require law enforcement agencies to set up check-points and establish legal penalties for violations (Richards et al. 2006; Wilder-Smith \& Freedman 2020). If the restrictions are voluntary, such as recommended social distancing, police may be limited in the way they can enforce the measures (Richards et al. 2006). Enforcement of social distancing can also increase the number of calls police departments receive due to reports of violations; even mundane activities, such as playing recreational sports in a park, may now initiate a police intervention (Schuppe 2020).

When these orders are being enforced by the police, one major question emerges: what specific measures should officers take when individuals violate mandatory 
measures, such as quarantines or travel restrictions? If officers are being instructed to limit police responses and avoid making arrests for misdemeanors, it can be challenging to simultaneously endorse increased police presence and response to enforce these orders. Although many agencies instructed officers to issue citations and fines, enforcement was largely inconsistent depending on the city or state of the agency (Mervosh, Lu, \& Swales 2020). Furthermore, officers may feel uncomfortable coming in close contact with those who are breaking quarantine or social distancing restrictions (Rothstein 2015). For example, during the SARS outbreak in 2002 and 2003, law enforcement officers around the world without sufficient PPE and training on infection control were hesitant to engage with individuals who had violated quarantine out of concern for their own health (Rothstein 2015). These orders must be communicated effectively by local, state, and federal leaders, the police, and public health officials to ensure that enforcement is consistent to effect voluntary compliance.

\section{Changes to Crime and Service Patterns}

A final major obstacle for law enforcement involves changes to crime and service patterns with many members of the public engaging in social distancing, in isolation, or under quarantine. As more people stay at home, police officers are reassigned to more populated areas of the city, which may leave rural areas more vulnerable to crime (Felbab-Brown 2020). In many of the communities most-affected by the COVID-19 pandemic, 911 calls increased dramatically, but fewer of these calls needed to be diverted to the local police department (Waldrop 2020). In fact, amidst the panic and the stay-at-home order implementation, many police departments reported general crime and violence reductions, with some offense exceptions (Bates 2020; Hermann et al. 2020; Poston 2020; Waldrop 2020). For instance, possibly and partly due to the result of stay-athome orders implemented in March 2020 and the increased personal and financial stress associated with the COVID-19 (and the public health measures), reports of assault and domestic violence increased in many cities (Kingkade 2020; Poston 2020). Given the potentially volatile and dangerous nature of domestic violence calls for officers, this increase may be cause for serious concern for police departments around the U.S. (Kingkade 2020) as the time period of the pandemic's effects on law enforcement lengthens.

\section{Directions for Future Law Enforcement Responses to Pandemics}

\section{Protecting the Officers}

In light of the challenges associated with responding to a pandemic like COVID-19, there are numerous directions for future responses to protect officers as well as members of the community. First and foremost, agencies should have a detailed plan in place for large-scale public health emergencies that specifically includes all actions that must be taken as soon as a pandemic event begins (Brito et al. 2009; Richards et al. 2006). This should also contain contingency planning to ensure there is a continuity of operations in the event of a reduced workforce, including shifting personnel performing 
non-essential functions into more critical roles (Brito et al. 2009; Richards et al. 2006). This may include determining which functions are critical and the minimum staff level needed, cross-training for sworn and non-sworn personnel to ensure that all essential tasks are completed, and a breakdown of the goods and services needed to complete these tasks (Brito et al. 2009). Departments should also have policies established for employee sick leave, family leave, remote work, hazard pay, and other human resources during a pandemic (Richards et al. 2006).

In line with public health recommendations, law enforcement agencies should work to provide training for all personnel on health and safety precautions during a pandemic, including modes of transmission of communicable diseases, protective measures to limit spread, and proper use of PPE equipment (Brennan Center for Justice 2020; Brito et al. 2009; Richards et al. 2006). Relatedly, to prepare for future pandemics, it is critical for agencies to constantly maintain their inventories of PPE, including masks, gloves, gowns, eye-wear, and hand sanitizer, to ensure that items have not expired and that a sufficient supply for agency personnel is maintained at all times (Brito et al. 2009; Sanberg et al. 2010). This may involve sharing space with other local agencies or developing a relationship with PPE suppliers prior to an emergency shortage (Brito et al. 2009). Finally, in efforts to limit exposure for officers and the public during a pandemic, agencies should consider setting up alternative virtual formats ahead of time for traditional in-person activities, such as in-service training, roll calls, and community engagement initiatives (PERF, 2020).

\section{Protecting the Community}

In order to effectively protect the community, law enforcement agencies should work to form effective and meaningful partnerships with local hospitals, public health departments, and other local police agencies to pool their knowledge and resources (Richards et al. 2006). These partnerships can foster the cross-training of personnel, as well as improve community education and public messaging (Richards et al. 2006; Vallee 2020). Using the recommendations of these partnerships, agencies should also specifically outline their protocols on the enforcement of social distancing, isolation, quarantine, and any other public health restrictions. These protocols should indicate specifically how these measures will be enforced and what the associated penalties will be (Richards et al. 2006).

Police agencies should also focus their efforts on their local community's immediate needs and utilizing problem-solving approaches to address them (Brennan Center for Justice 2020). In other words, the focus of the agency should be directed to reducing community concerns and anxieties. In efforts to focus agency resources, departments should consider following the lead of many of the agencies listed above as examples as they respond to the future pandemics and issue warnings, summons, or citations for minor or non-violent offenses, such as misdemeanors, probation/parole violations, evictions, and other offenses (Vera Institute of Justice 2020). These plans should also be frequently reviewed and updated to incorporate new information and lessons learned from past experiences (Brito et al. 2009). 


\section{Final Thoughts}

Ultimately, the COVID-19 pandemic certainly caught many members of law enforcement and the public unprepared initially, and law enforcement's response to the pandemic continues to evolve. Unfortunately, this is not to be unexpected when there is literally no existing "play book" for law enforcement for managing a pandemic of this size and scale. Law enforcement officers, along with the healthcare workers in hospitals, doctor's offices, and assisted living facilities and nursing homes, are truly those individuals on the front lines fighting this war against COVID-19. We will emerge from this, and the individuals on the front lines, including law enforcement, will continue to play a vital role in the U.S. and the world's response to the pandemic. Please stay well, and stay safe.

\section{References}

Barba, M. (2020, March 12). Coronavirus fears prompt call for SF police to halt arrests in non-violent cases. San Francisco Examiner.https:/www.sfexaminer.com/news/coronavirus-fears-prompt-call-for-sf-policeto-stop-issuing-citations-making-arrests-in-non-violent-cases/

Barr, L. (2020, March 14). No days off for police departments during coronavirus outbreak. ABC News. https://abcnews.go.com/Health/days-off-police-departments-coronavirus-outbreak/story?id=69583481

Bates, J. (2020, April 2). Police departments, sheriffs' offices across the U.S. grapple with COVID-19's impact on public safety-And their own. TIME. https:/time.com/5812833/coronavirus-police-departments/

Brennan Center for Justice. (2020, March 27; updated 2020, March 30). Police responses to COVID-19. https://www.brennancenter.org/our-work/research-reports/police-responses-covid-19

Brito, C. S., Luna, A. M., \& Sanberg, E. L. (2009). Benchmarks for developing a law enforcement pandemic flu plan. US Department of Justice: Bureau of Justice Assistance. https://www.publicsafety.gc. ca/lbrr/archives/cnmcs-plcng/cn34974-eng.pdf.

Browning, A. (2020, March 18). Miami police Dept. screening its employees, visitors for coronavirus symptoms. WSVN News. https://wsvn.com/news/local/miami-dade/miami-police-dept-screening-itsemployees-visitors-for-coronavirus-symptoms/

Cave, D. \& Dahir, A.L. (2020, April 2). How far should police go in enforcing coronavirus lockdowns? The New York Times. https://www.nytimes.com/2020/04/02/world/australia/coronavirus-police-lockdowns. html

Center for Disease Control and Prevention (CDC). (2020). What Law Enforcement Personnel Need to Know about Coronavirus disease 2019 (COVID-19). https://www.cdc.gov/coronavirus/2019ncov/downloads/guidance-law-enforcement.pdf

Conley, A. (2020, March 23). Omaha police precincts to be closed to public; call center will handle lowpriority incidents. Omaha World Herald. https:/www.omaha.com/livewellnebraska/health/omaha-policeprecincts-to-be-closed-to-public-call-center/article_9dd80599-1ea0-5266-a27e-c4b79340f4fc.html

Felbab-Brown, V. (2020, April 7). How COVID-19 is changing law enforcement practices by police and by criminal groups. Brookings. https://www.brookings.edu/blog/order-from-chaos/2020/04/07/how-covid19-is-changing-law-enforcement-practices-by-police-and-by-criminal-groups/

Garcia, U.J. (2020, March 24). Phoenix police to decrease arrests for nonviolent crimes, chief says. $A Z$ Central. https://www.azcentral.com/story/news/local/phoenix/2020/03/24/phoenix-police-decreasearrests-nonviolent-crimes-chief-jeri-williams-says-coronavirus/2912891001/

Haas, K. (2020, March 25). Fewer arrests, jail bookings in Rockford during coronavirus pandemic. Rockford Register Star. https://www.rrstar.com/news/20200325/fewer-arrests-jail-bookings-in-rockford-duringcoronavirus-pandemic

Hermann, P., Morse, D., \& Jackman, T. (2020, March 27). Patrolling the beat while keeping a distance: Police officers face new rules, rhythms amid pandemic. The Washington Post. https://www.washingtonpost. $\mathrm{com} /$ local/public-safety/patrolling-the-beat-while-keeping-a-distance-police-officers-face-new-rulesrhythms-amid-pandemic/2020/03/27/334b3602-6afc-11ea-abef-020f086a3fab_story.html 
Iannelli, J. (2020, March 20). As COVID-19 spreads in South Florida. The Appeal: Miami-Dade police department instructs officers to issue citations for all misdemeanor offenses https://heappeal.org/miamicovid-19-arrests/.

International Association of Chiefs of Police (IACP). (2020). COVID-19 Information for Law Enforcement: General Fact Sheet. https://www.theiacp.org/sites/default/files/IACP Covid-19 General Factsheet.pdf

Kingkade, T. (2020, April 5). Police see rise in domestic violence calls amid coronavirus lockdown. NBC News. https:/www.nbcnews.com/news/us-news/police-see-rise-domestic-violence-calls-amidcoronavirus-lockdown-n1176151

Kucher, K. (2020, March 24). Chula Vista police eyeing using drones in the fight against COVID-19. San Diego Union Tribune. https://www.sandiegouniontribune.com/news/public-safety/story/2020-03-24 /chula-vista-police-eyeing-using-drones-in-the-fight-against-covid-19

Lipscomb, J. (2020, March 12). Miami-Dade police suspend evictions amid coronavirus spread. Miami New Times. https://www.miaminewtimes.com/news/coronavirus-in-miami-police-suspend-eviction-activity11592335

Luna, A. M., Brito, C. S., \& Sanberg, E. A. (2007). Police planning for an influenza pandemic: case studies and recommendations from the field. Police Executive Research Forum. https://www.publicsafety.gc. ca/lbrr/archives/cnmes-pleng/cn89173109-eng.pdf

Mallin, A. \& Barr, L. (2020, March 18). Police implement sweeping policy changes to prepare for coronavirus spread. ABC News. https://abcnews.go.com/US/police-implement-sweeping-policy-prepare-coronavirusspread/story?id=69672368

Manna, N. (2020, March 17). Fort Worth police will give citations for low-level crimes amid coronavirus outbreak. Fort Worth Star-Telegram. https://www.star-telegram.com/news/coronavirus/article241254951. html

Margolin, J. (2020, March 23). White supremacists encouraging their members to spread coronavirus to cops, Jews, FBI says. ABC News. https://abcnews.go.com/US/white-supremacists-encouraging-membersspread-coronavirus-cops-jews/story?id=69737522

Martin, D. (2020, March 14). Topeka police enhance safety measures due to COVID-19. MSN. https://www. msn.com/en-us/news/us/topeka-police-enhance-safety-measures-due-to-covid-19/ar-BB11bSkC

Maruschak, L. M., Sabol, W. J., Potter, R. H., Reid, L. C., \& Cramer, E. W. (2009). Pandemic influenza and jail facilities and populations. American Journal of Public Health, 99(S2), S339-S344.

Melamed, S., \& Newell, M. (2020, March 17). With courts closed by pandemic. The Philadelphia Inquirer: Philly police stop low-level arrests to manage jail crowding https://www.inquirer. com/health/coronavirus/philadelphia-police-coronavirus-covid-pandemic-arrests-jail-overcrowding-larrykrasner-20200317.html.

Mervosh, S., Lu, D., \& Swales, V. (2020, April 7). See which states and cities told residents to stay at home. The New York Times. https://www.nytimes.com/interactive/2020/us/coronavirus-stay-at-home-order. html?auth=login-google

Muckenfuss, A. (2020, March 24). Policing the pandemic of 1918. National Law Enforcement Museum. https:/lawenforcementmuseum.org/2020/03/24/policing-the-pandemic-of-1918/

National Police Foundation (NPF). (2020). COVID-19 Resources for Law Enforcement. https://www. policefoundation.org/covid-19/

Osborne, M. (2020, March 19). Reacting to coronavirus. WMOT: MNPD limits officer in-person calls https://www.wmot.org/post/reacting-coronavirus-mnpd-limits-officer-person-calls\#stream/0.

Plaue, N., \& Colarossi, N. (2020, February 28). Photos show how the 1918 flu pandemic brought the world to its knees. Business Insider. https://www.businessinsider.com/1918-flu-pandemic-pictures-2012-8

Police Executive Research Forum. (2020) Responding to the COVID-19 Coronavirus. https://www. policeforum.org/coronavirus

PoliceOne. (2020). Coronavirus (COVID-19). https://www.policeone.com/coronavirus-covid-19/

Poston, B. (2020, March 18). Arrests by LAPD and Sheriff's Department drop amid coronavirus outbreak. Los Angeles Times. https:/www.latimes.com/california/story/2020-03-18/lapd-arrests-crime-coronavirus

Richards, E. P., Rathbun, K. C., Brito, C. S., \& Luna, A. (2006). The role of law enforcement in public health emergencies: A special considerations for an all-hazards approach. US Department of Justice: Bureau of Justice Assistance. https://www.ncjrs.gov/pdffiles1/bja/214333.pdf.

Rothstein, M. A. (2015). From SARS to Ebola: Legal and ethical considerations for modern quarantine. Indiana Health Law Review, 12, 227-280.

Sanberg, E. L., Brito, C. S., Luna, A. M., \& McFadden, S. M. (2010, September). A guide to occupational health and safety for law enforcement executives. Police Executive Research Forum. https://www. policeforum.org/assets/docs/Free_Online_Documents/Public_Health/a\%20guide\%20to\%20 occupational $\% 20$ health $\% 20$ and $\% 20$ safety $\% 20$ for $\% 201$ aw $\% 20$ enforcement $\% 20$ executives $\% 202010$.pdf 
Schuppe, J. (2020, April 4). Police get creative to stay safe and keep order as coronavirus spreads. NBC News. https://www.nbcnews.com/news/us-news/police-get-creative-stay-safe-keep-order-coronavirus-spreadsn1176211

Schutz, E. (2020, March 21). Dallas 911 call takers to begin asking coronavirus-related questions in some cases, police say. The Dallas Morning News. https:/www.dallasnews.com/news/public-health/2020/03 /21/dallas-911-call-takers-to-begin-asking-coronavirus-related-questions-in-some-cases-police-say/

Stagoff-Belfort, A. (2020, March 27). Law enforcement best practices can help halt the spread of COVID-19 by keeping people out of jail. Vera Institute of Justice. https://www.vera.org/blog/covid-19-1/lawenforcement-best-practices-can-help-halt-the-spread-of-covid-19-by-keeping-people-out-of-jail

Vallee, J. (2020, April 7). Regional law enforcement agencies partnering to combat COVID-19 fraud. The Westerly Sun. https:/www.thewesterlysun.com/news/covid-19/regional-law-enforcement-agenciespartnering-to-combat-covid-19-fraud/article_c80136d8-7908-11ea-b734-d31c06dd0247.html

Vera Institute of Justice. (2020). Guidance for Preventive and Responsive Measures to Coronavirus by Police and Law Enforcement. https://www.vera.org/downloads/publications/coronavirus-guidance-police-lawenforcement.pdf

Waldrop, T. (2020, April 1). Coronavirus has police everywhere scrambling to respond as their forces are reduced. CNN. https://www.cnn.com/2020/04/01/us/police-coronavirus/index.html

Whitlow, J. (2020, March 19). Harford 911 operators screening for coronavirus over phone, sheriff's office taking precautions. The Baltimore Sun. https://www.baltimoresun.com/maryland/harford/aegis/cng-agsheriff-coronavirus-20200319-ndvorvnxhjcjp126twjsjkv2wa-story.html

Wilder-Smith, A., \& Freedman, D. O. (2020). Isolation, quarantine, social distancing and community containment: Pivotal role for old-style public health measures in the novel coronavirus (2019-nCoV) outbreak. Journal of Travel Medicine, 27(2), 1-4.

Winton, R., \& Tcheckmedyian, A. (2020, March 17). Coronavirus has authorities putting more police on streets, releasing inmates from jails. Los Angeles Times. https://www.latimes.com/california/story/202003-17/coronavirus-has-authorities-putting-more-police-on-streets-releasing-inmates-from-jails

York, J.A. (2020, April 4). Law enforcement lays out coronavirus-crackdown across Santa Cruz County. Santa Cruz Sentinel. https:/www.santacruzsentinel.com/2020/04/04/law-enforcement-lays-outcoronavirus-crackdown-across-santa-cruz-county-2/

Publisher's Note Springer Nature remains neutral with regard to jurisdictional claims in published maps and institutional affiliations.

Wesley G. Jennings is Chair and Professor in the Department of Criminal Justice \& Legal Studies at the University of Mississippi. He has over 250 publications, his h-index is 52 (i-index of 154), and he has over 9,000 citations to his published work. He is a member of the American Society of Criminology, a Lifetime Member of both the Academy of Criminal Justice Sciences and the Southern Criminal Justice Association, and a Fellow of the Academy of Criminal Justice Sciences.

Nicholas M. Perez is an Assistant Professor in the School of Criminology, Criminal Justice, and Emergency Management at California State University, Long Beach (CSULB). He has authored or co-authored peerreviewed journal articles in Aggression and Violent Behavior, the Annual Review of Clinical Psychology, Crime \& Delinquency, theJournal of Contemporary Criminal Justice, Policing: An International Journal of Police Strategies and Management, theJournal of Youth and Adolescence, Security Journal, the Journal of Criminal Justice Education, and Child Abuse \& Neglect. 